\title{
Improving Innovation Performance by Convergence in Open Innovation: Evidence from Software Firms in Sri Lanka
}

\author{
S. R. Yapa \\ University of Colombo, Sri Lanka \\ R. Senathiraja \\ University of Colombo, Sri Lanka \\ I. Kauranen \\ Aalto University, Finland
}

\begin{abstract}
Open innovation, which encourages firms to use external knowledge and external partners to accelerate innovation, has become a popular approach among organisations globally. Researchers have highlighted multiple benefits that open innovation offers. Extant literature often discusses factors of open innovation that increase innovation performance. However, open innovation does not always bring higher innovation performance and reasons for this are not adequately addressed in the existing literature. The objective of this research study is to increase understanding of factors that can hinder innovation performance in open innovation implementations. Special attention has given to convergence. In this case, convergence refers to alignment and coordination between innovation partner firms. The empirical data for this research study will be gathered from software firms
\end{abstract}

Corresponding Author:

Mr. S. R. Yapa is a PhD candidate at the University of Colombo, Sri Lanka. E-mail: shantayapa@gmail.com 
in Sri Lanka. The background for this study is the software firms in Sri Lanka which have not reached the expectation that have been placed on them.

\section{Keywords}

Absorptive capacity, Convergence, Innovation performance, Open innovation

\section{Introduction}

Open innovation (OI) is broadly defined as the use of purposive inflows and outflows of knowledge to accelerate internal innovation and to expand the markets for external use of innovation respectively (Chesbrough, 2003). Openness has become a trend in innovation management (Lopez \& Carvalho, 2018) and attracted wide academic attention (Kim, Kim, \& Lee, 2015). Researchers highlight multiple benefits of open innovation such as improved performance (Chen, Zhao, \& Wang, 2014; Kim et al, 2015; Foroughi, Buang, Senik, Hajmirsadeghi, \& Bagheri, 2015), new product development (Un, Cuervo-Cazurra, \& Asakawa, 2010), profitability (Noh, 2015), competitiveness (Al-Belushi, Stead, \& Burgess, 2015), and portfolio diversity (Colombo, Piva, \& Rossi-Lamastra, 2014). Reducing path dependency (Almirall \& Casadesus-Masanell, 2010; Prabhu, Chandy, \& Ellis, 2005), sales growth (Chaston, 2013), financial performance (Mazzola, Bruccoleri, \& Perrone, 2016; Fiegenbaum, Ihrig, \& Torkkeli, 2014), and higher employee job satisfaction (Lee, Kao, \& Yang, 2014) are some other benefits. According to Chesbrough (2017), openness is a strategy for firms.

OI that denotes an organisation's ability to attract a range of external resources to meet their needs to innovate (Verbano, C., Venturini, K., \& Wasser, A., 2013) is critical to innovation performance and therefore firms connect their internal Research and Development (R\&D) functions with external entities to promote innovations. A model for open innovation is given in Figure 1.

Cheng and Huizingh (2014) have observed that all three types of OI activities namely outside-in, inside-out, and coupled activities are significantly and positively related to four dimensions of innovation performance: new product/service innovativeness, new product/service 
success, customer performance, and financial performance. However, there are controversies in respect to the impact of OI on innovation performance (Greco, Locatelli, \& Lisi, 2017). According to Cheng and Shiu (2015), the relationship between OI and innovation performance is not direct and some argue that increased OI can reduce innovation performance (Berchicci, 2013; Garriga, Von Krogh, \& Spaeth, 2013; Bengtsson, et al, 2015).

\section{Figure 1: A Model for Open Innovation}

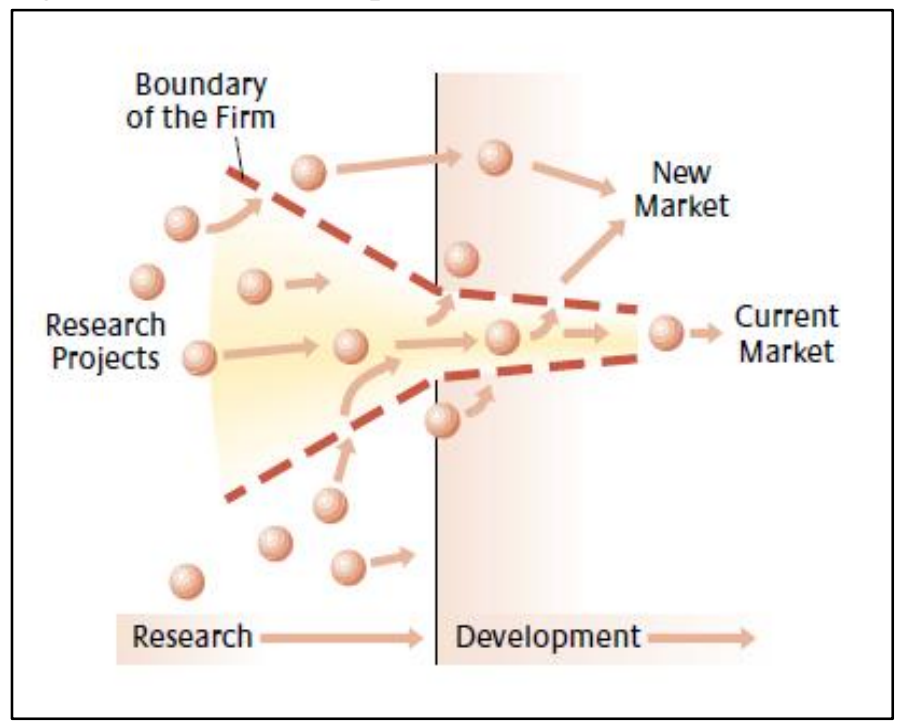

Source: Chesbrough, 2003

\section{Objectives of the Study}

Extant literature on $\mathrm{OI}$ and innovation performance provides inconsistent arguments and inconclusive results (Greco et al, 2017; Cheng \& Shiu, 2015; Bengtsson et al, 2015). Popular innovation theories fall short in explaining differences in innovation performance, especially effects of innovation partners (Cheng \& Huizing, 2014; Bengtsson et al, 2015; Pullen, Weerd-Nederhof, Groen, \& Fisscher, 2012). Many firms struggle to harness value from OI initiatives (Salter, A., Ter wal, A. L. J., \& Criscuolo, P., \& Alexy, O., 2014) as they fail to engage external actors (Dahlander \& Piezunka, 2014). Challenges that firms face when involving external actors in OI have become a popular area for research (Foss, Laursen, \& Pedersen, 2011; Afuah \& Tucci, 2012; Felin \& Zenger, 2014; Hossain \& Anees-urRehman, 2016). Too much openness may result in negative innovation 
performance in the long term as firms may lose attention to and control over their core competencies (Enkel, Gassmann, \& Chesbrough, 2009; Laursen \& Salter 2006; Kim, Kim, \& Foss, 2016). Bogers et al (2017) emphasize the importance of examining the effectiveness of $\mathrm{OI}$ in terms of its implications for innovation performance. Given the variance in the effectiveness of OI, its context dependency has been an area of interest for researchers (Huizingh, 2011) including the strategic orientation of firms (Cheng \& Huizingh, 2014).

In this research study, we focus on convergence with partner firms when trying to explain innovation performance. Here, we define convergence as the alignment and the coordination with partner firms. Further, research on convergence is needed because despite the fact that convergence has proven to be an important factor in studies on inter-organisational networks, convergence has not been extensively studied in the context of open innovation. In conducting our empirical study, Sri Lankan software industry provides a fertile ground, as their open innovation initiatives have not lead to expected innovation performance.

\section{Literature Review}

The increasing propensity of firms to work across their traditional boundaries of operations is addressed by the concept of OI (Mina, Bascavusoglu, \& Hughes, 2014). Extant literature points out many factors that influence OI. Among them are absorptive capacity (Cohen \& Levinthal, 1990; Murovec \& Prodan, 2009; De Zubielqui, Jones, \& Lester, 2016; Matusik \& Heely, 2005), dynamic innovation capability (Teece, Pisano, \& Shuen, 1997), ambidexterity (March, 1991; Tushman \& O’Reilly, 1996; Andriopoulos \& Lewis, 2009; Ferrary, 2011), inertia (Huang, Lai, Lin, \& Chen, 2013; Godkin, 2010), and in-bound and out-bound OI practices (Enkel et al, 2009; Bianchi, Croce, Dell'Era, Benedetto, \& Frattini, 2015; West \& Bogers, 2014; Fernandes, Cesario, \& Barata, 2017; Popa, SotoAcosta, \& Martinez-Conesa, 2017). These are mainly internal factors of the firm. As OI goes beyond the boundaries of the focal firm (Munir, Linaker, Wnuk, Runeson, \& Regnell, 2018; Powell, Koput, \& Smith-Doerr, 1996), these concepts and theories fall short in answering questions such as why do firms have varying levels of success with different OI partners (Bengtsson et al, 2015)? why do firms have varying success in different OI projects 
with the same partners (Cheng \& Huizing, 2014; Bengtsson et al, 2015)? how do firms choose their OI partners (West \& Gallagher, 2006)? what factors a firm will look for in selecting OI partners (Rusanen, 2013)? and given the strengths and weaknesses of a firm, from whom it would be most beneficial to learn (Von, Netland, \& Worter, 2018)? Based on the results of empirical studies, Lee, Cho and Shin (2015) argue that effectiveness of OI practices of global Information Technology (IT) companies is not clear. Overall, the factors captured by the existing OI theories and concepts do not sufficiently explain innovation performance.

Innovations happen increasingly in networks where actors of different backgrounds are involved (Kallio, Harmaakorpi, \& Pihkala, 2010) and as such inter-organisational networks have become an area of interest for innovation researchers in recent years (Najafian \& Colabi, 2014; De Noni, Orsi, \& Belussi, 2018). According to Powell et al (1996), the locus of innovation is in networks instead of individual organisations when the knowledge base of an industry is both complex and expanding and the sources of expertise are widely dispersed. Rothwell (1977) points out that the success of innovation largely depends on long-term relationships and close interaction of agents external to the firm. Networking in OI can be horizontal, vertical, or a combination of these and the corresponding network profile has a significant role in innovation performance (Hossain \& Kauranen, 2015). Among firms, the number of joint product development projects has increased significantly. Innovation networks involving competing firms is not anymore an exception but is typical. Convergence in technological systems has increased. In accordance, Soh and Roberts (2003) have emphasized the importance of empirical investigation of integrated innovation networks. It is noteworthy that the importance of convergence in the form of alignment and coordination has been extensively examined in research studies on inter-organisational networks but convergence has not been studied in OI research extensively. Examples of convergence studies that have the point of departure in organisational networks include Achrol, Scheer and Stern (1990), Bourgeois (1980), Corsaro \& Snehota (2011), Callon, Lareedo, Rabeharisoa, Gonard and Leray (1992), Emden, Calantone and Droge (2006), Ruekert \& Walker (1987), Pullen et al. (2012), Spekman, Isabella and MacAvoy (2000), and Duysters \& Man (2003). Many well-established management theories 
would offer a sound point of departure for extending OI research such that convergence in the form of alignment and coordination would be understood better. Among such studies are: the resource base view (Barney, 1991), the dynamic capability framework (Teece et al, 1997), the knowledge based view (Kogut \& Zander, 1992), the transaction cost economics theory (Williamson, 1975), the institutional theory (Meyer \& Rowan, 1977), and the actor network theory (Latour, 1996).

\section{Theoretical and Empirical Gaps}

Extant literature provides inconsistent arguments and inconclusive results (Caputo, Lambert, \& Cammarano, 2016; Cheng \& Shiu, 2015; Bengtsson et al, 2015). Popular innovation theories do not adequately explain OI differences in innovation performance (Cheng \& Huizing, 2014; Bengtsson et al., 2015). Many firms struggle to harness value from OI initiatives (Salter et al., 2014; Lee \& Shin, 2017) as they fail to engage external actors (Dahlander \& Piezunka, 2014). Challenges firms face involving external actors in OI have become a popular area for research (Foss et al., 2011; Afuah \& Tucci, 2012; Felin \& Zenger, 2014; Hossain \& Anees-ur-Rehman, 2016). Too much openness results in negative innovation performance in the long term as firms may lose attention and control over core competence (Enkel et al., 2009; Laursen \& Salter 2006; Kim et al., 2016). Naqshbandi $(2016,2018)$ emphasizes the importance of focusing on external adaptation and internal integration for OI success. In this present study, we argue that convergence in the form of alignment and coordination as a variable has a potential of bringing in new insights in to OI literature.

The need for compatible structures and management practices, and the importance of effective coordination of activities are emphasized by Larsen, Bandara, Mohamed, \& Unantenne (2016) in their study of universityindustry collaborations. Although social theories highlight convergence as an important aspect of inter-organisational networks (Callon, 1992; Miere \& Missonier, 2012), the existing innovation theories have not adequately addressed the impact of convergence on OI performance. Furthermore, empirical evidence as regards to OI practices and OI performance are not consistent (Cheng \& Shiu, 2015). OI research studies show that when adopting OI strategies organisations benefit differently and the reasons for 
these differences are not explained (Saebi \& Foss, 2015). The effect of OI on innovation and financial performance of global IT firms is an underresearched area (Lee et al., 2015). Further, to the best of the knowledge of the researcher, there are no published empirical research findings covering the Sri Lankan software industry to understand how OI practices in general and, specifically how inter-organisational convergence influence innovation performance.

As cited by Rampersad, Quester and Troshani (2010) and Lakemond, Bengtsson, Laursen and Tell (2016) extant literature predominantly has a focus on firm perspectives ignoring the collective network level (Provan \& Milward, 1995). Consequently, in further studies it is important to study management processes among innovation networks (Moller \& Svahn, 2009). OI being a multi-faceted (Randhawa, Wilden, \& Hohberger, 2016) and multi-level phenomena (Bogers et al, 2017) demands distinct contexts and different levels of analysis in research designs (Lopez \& Carvalho, 2018). The present research will go beyond the firm perspective and will attempt to bring new insights from a network level perspective.

\section{Inbound Open Innovation and Innovation Performance}

Many scholars have emphasized the relationship between inbound OI practices and innovation performance of organisations (Parida, Westerberg, \& Frishammar, 2012; Cheng \& Huizing, 2014; Cheng, Yang, \& Sheu, 2016; Kim et al., 2016; Remneland-Wikhamn \& Wikhamn, 2011; Pedrosa, Valling, \& Boyd, 2013; Lopez-vega, 2016; Billington \& Davidson, 2013; Sisodiya, Johnson,, \& Gregorie, 2013; Kim et al, 2016; RemnelandWikhamn \& Knights, 2011; Pedrosa et al, 2013; Lopez-vega, Tell, \& Vanhavebeke, 2016). Harnessing technical competencies of partner firms (Bianchi et al, 2015), staying ahead of competition (Asakawa, Nakamura, \& Sawada, 2010), new product development (Sisodiya et al, 2013), and new ideas that can create competitive advantage (Billington \& Davidson, 2013) are some of the benefits of inbound OI cited by scholars.

\section{Outbound Open Innovation and Innovation Performance}

Both in-bound and out-bound OI activities can have a positive impact on innovation performance (Parida et al., 2012; Cheng \& Huizing, 2014; Cheng et al., 2016). Exploitation of the organisation's current base of 
knowledge and technologies (He \& Wong, 2004), learning opportunities (March, 1991), market expansion (Adam, Ong, \& Pearson, 1988; Koruna, 2004), multiplication of own technologies (Kutvonen, 2009), and improved innovation performance (Huizing, 2011; West \& Bogers, 2014) have been highlighted in extant literature as benefits of outbound OI practices.

\section{Roles of Absorptive Capacity in Open Innovation Practices and Innovation Performance}

Cohen and Levinthal (1990) described absorptive capacity as a firm's ability to recognize the value of external knowledge, to assimilate it, and to apply it to commercial ends. Absorptive capacity is associated with both inbound and outbound OI practices (Spithoven, Clarysse, \& Knockaert, 2010; Nitzsche, Writz, \& Gottel, 2016; Vanhaverbeke, 2006) and plays a mediating role in the relationship between managerial ties among partner firms and the two types of OI -inbound and outbound OI (Naqshbandi, 2016). Zahra and George (2002) argue that knowledge acquisition, assimilation, transformation, and exploitation are capabilities build upon each other to produce dynamic organisational capabilities in order to enhance innovation performance. Spithoven et al. (2010); Pilav-Velic \& Marjanovic (2016); Escribano, Fosfuri and Tribo (2009); De Zubielqui et al, 2016; and Kim et al. (2016) have emphasized the positive relationship between absorptive capacity and innovation performance.

Sikimic, Chiesa, Frattini and Scalera (2016) empirically show the positive interaction between technology inflows and outflows, on the one hand, and technological synergies, on the other hand, in the development of absorptive capacities. The complementarity between external knowledge flows and absorptive capacity has been emphasized by Escribano et al. (2009), and Ferto, Molnar and Toth (2016). Pilav-Velic and Marjanovic (2016) have observed that organisations which have high absorptive capacities and which aggressively source knowledge from external sources such as customers, suppliers, and public institutions have more often introduced new radical innovations. Limited absorptive capacity can be a barrier to the adoption of OI (Huang, Lai, \& Huang, 2015).

A moderating approach has been followed by some researchers drawing on Cohen and Levinthal's (1990) description which states that a firm's 
absorptive capacity determines the extent to which extramural knowledge is utilized. Among the researchers who have used absorptive capacity as a moderating variable are Flor, Cooper and Oltra (2017), Clausen (2013), Escribano et al. (2009), Fabrizio (2009), Ghisetti, Marzucchi and Montresor (2015), Huang and Rice (2012), Laursen and Salter (2006), Cheng et al. (2016), Rothaermal and Alexandre (2009), Lopes and Carvalho (2018), Lewandowska (2014), Berchicci (2013), and Enkel and Heil (2014).

\section{Role of Convergence}

We borrow the term convergence from the actor network theory (Latour, 2005; Callon, 1999; Meirer \& Missionier, 2012) where alignment and coordination are considered as the two key characteristics. Although the importance of inter-organisational convergence in the form of alignment and coordination has not much been discussed in relation to innovation performance, its association with effectiveness of relationships has been emphasized by many researchers. Scholars increasingly consider collaborative innovation networks as an effective process that enables a firm's knowledge transfer under the context of OI (Xie, Fang, \& Zeng, 2016). Innovation has evolved from being a result of the efforts of an individual or a single firm to an interactive process between firms (Wynarczyk, Piperopoulos, \& McAdam, 2013). Hernandez-Vivanco, Bernardo and Cruz-Cazares (2016) emphasize the positive moderation effect that external cooperation has with innovation performance. Leminen, Turunen and Westerlund (2015) emphasized the need of further studies on the degree of openness and closeness of innovation networks that have multiple collaborative stakeholders. As OI is inherently a dynamic process, Appleyard and Chesbrough (2017) have pointed out the need of bringing dynamic factors to research on OI. In line with this, we intend to investigate alignment and coordination as dynamic factors of OI.

We consider goal complementarity as the first dimension of alignment. Clearly understood objectives and strategies among partner firms support the necessary information flows (Pullen et al., 2012) for successful codevelopment of products (Emden et al., 2006). Cooperation between 
partners is increasingly based on the alignment of goals and objectives of partners (Spekman et al., 2000). Well aligned objectives and goals significantly improve cooperation between partners (Duysters \& Man, 2003; Behnam, Cagliano, \& Grijalvo, 2018). Similar management styles and culture help in building a conducive partner match (Bucklin \& Sengupta, 1993). Domain similarity and goal compatibility increase the effectiveness of inter-organisational relationships (Ruekert \& Walker, 1987). Inter-partner resource alignment is a significant element in knowledge transfer (Tsai \& $\mathrm{Wu}, 2011)$. High level of goal complementarity is positively related to high innovation performance (Pullen et al., 2012). It is important to have noncompeting, complementary, and achievable goals through the same business model (Emden et al., 2006). Achrol et al. (1990) emphasize the necessity of organisational compatibility in terms of strategy and Bourgeois (1980) point out the importance of goal consensus in coalitions. The depth of collaboration with different partners such as value chain partners, universities, competitors, and firms in other industries is positively related to innovation performance (Bengtsson et al., 2015).

Resource complementarity is the second dimension we use to measure alignment. Haythornthwaite (1996), Tichy, Tushman and Fombrun (1979), and Pullen et al. (2012) emphasize that in inter-organisational relationships it is important to exchange physical and organisational resources between cooperating partner firms in order to achieve the common goals. Uzzi (1996) argues that organisational networks operate in an embedded logic of exchange where inter-firm resource pooling, cooperation, and coordinated adaptation promote economic performance. Tomlinson (2010) emphasizes the importance of the strength of vertical ties for innovation performance. These results of previous research constitute grounds for our intended examination of the effect of convergence on innovation performance.

We consider knowledge complementarity as the third dimension of alignment. Cohen and Levinthal (1990) argue that the ability to use newly acquired external knowledge to solve problems is enhanced when new knowledge is related to the existing knowledge of the organisation. 
Knowledge integration needs to be facilitated through network coordination for innovation success (Hopkins, Tidd, Nightingale, \& Miller, 2011; De Mattos, Kissimoto, \& Laurindo, 2018). Similar knowledge elements ease the integration of acquired knowledge with the existing knowledge bases (Kogut \& Zander, 1992). Therefore, our suggestion is that knowledge complementarity should be used as an indicator when operationalizing alignment which is one characteristic of convergence.

We consider the second characteristic of convergence as coordination. Innovation is an interactive process, thus relationships and cooperation with stakeholders are vital in innovation (Gomez, Olaso, \& ZabalaIturriagagoitia, 2016). OI requires firms to develop routines and practices for coordination with external sources ( $\mathrm{Lu}$, Yuan, \& Wu, 2017) to avoid deviating from the objectives (Arashpour, Abbasi, Hosseini, \& Yang, 2017). Managerial ties among partner firms support OI (Naqshbandi, 2016). Interfirm knowledge monitoring mechanisms that motivate employees to stay involved in the knowledge community may trigger attentions to other firm's innovative ideas. Thus, we emphasize the importance of coordination.

Raas, Dumbach, Danzinger, Bullinger and Moeslein (2013) and Moretti and Biancardi (2018) emphasize on the positive effect of social capital of firm on OI and innovation performance. Kim et al. (2016) suggest further research on transitioning attentional structures. With this, they refer to a specific coordinating mechanism. Jansen, Van De Bosch and Volberda (2005) and Van De Bosch, Volberda and De Boer (1999) describe three broad types of intra-organisational capabilities related to absorptive capacity: coordination, socialization, and change capabilities. Therefore, the importance of coordination, one of the central dimensions we attempt to test has been already established within inter-organisational networks literature. Tsai and $\mathrm{Wu}$ (2011) have also emphasized the relationship between absorptive capacity and coordination among network partner firms. Coordination is necessary in knowledge transfer (Becker \& Eube, 2018). Lim (2009) argues that absorptive capacity is primarily a function of 
connectedness. In our intended research study, we attempt to address this need by bringing in convergence as a central dimension.

A summary of the justification of the use of the variables by prior researchers is presented in Table 1 .

Table 1: A summary of the Justification of the Use of the Variables by Prior Researchers

\begin{tabular}{|c|c|}
\hline Relationship & References \\
\hline $\begin{array}{l}\text { Inbound OI and } \\
\text { innovation } \\
\text { performance }\end{array}$ & $\begin{array}{l}\text { Parida et al. (2012); Cheng and Huizing (2014); Cheng et al. } \\
\text { (2016); Kim et al. (2016); Asakawa et al. (2010); } \\
\text { Remneland-Wikhamn and Wikhamn (2011); Pedrosa et al. } \\
\text { (2013);Lopez-vega (2016); Billington and Davidson (2013); } \\
\text { Sisodiya et al. (2013) }\end{array}$ \\
\hline $\begin{array}{l}\text { Outbound OI and } \\
\text { innovation } \\
\text { performance }\end{array}$ & $\begin{array}{l}\text { He and Wong (2004); March (1991); Adam et al. (1998); Koruna } \\
\text { (2004); Huizing (2011); West and Bogers (2014); Parida et al. } \\
\text { (2012); Cheng and Huizing (2014); Cheng et al. (2016) }\end{array}$ \\
\hline \multicolumn{2}{|c|}{ Convergence on inbound \& outbound OI and innovation performance } \\
\hline $\begin{array}{l}\text { Alignment: goal } \\
\text { complementarity }\end{array}$ & $\begin{array}{l}\text { Behnam et al. (2018); Pullen et al. (2012); Ruekert and Walker } \\
\text { (1987); Spekman et al. (2000); Duysters and Man (2003); } \\
\text { Bourgeois (1980); Emden et al. (2006) }\end{array}$ \\
\hline $\begin{array}{l}\text { Alignment: } \\
\text { resource } \\
\text { complementarity }\end{array}$ & $\begin{array}{l}\text { Tsai and Wu (2011); Haythornthwaite (1996); Tichy et al.(1979); } \\
\text { Pullen et al. (2012) }\end{array}$ \\
\hline $\begin{array}{l}\text { Alignment: } \\
\text { knowledge } \\
\text { complementarity }\end{array}$ & Kogut and Zander (1992); Hopkins et al. (2011) \\
\hline Coordination: & $\begin{array}{l}\text { Becker (2014); Becker and Eube (2018); Tomlinson (2010); } \\
\text { Hopkins et al. (2011); Naqshbandi (2016); Lu et al. (2017); } \\
\text { Kim et al. (2016); Tsai and Wu (2011); De Mattos et al. (2018); } \\
\text { Arashpour et al. (2017) }\end{array}$ \\
\hline $\begin{array}{l}\text { Absorptive capacity } \\
\text { on inbound \& } \\
\text { outbound OI and } \\
\text { innovation } \\
\text { performance }\end{array}$ & $\begin{array}{l}\text { Flor et al. (2017); Clausen (2013); Escribano et al. (2009); Fabrico } \\
\text { (2009); Ghisetti et al (2015); Huang and Rice (2012); Laursen and } \\
\text { Salter (2006); Cheng et al. (2016); Diaz-Diaz and Saa-Perez } \\
\text { (2014); Rothaermal and Alexandre (2009); Lopes and Carvalho } \\
\text { (2018); Lewandowska (2014); Berchicci et al. (2013); Enkel and } \\
\text { Hel (2014); Ahn et al. (2016); Cheng and Shiu (2015); } \\
\text { Naqshbandi (2016); Kim et al. (2016) }\end{array}$ \\
\hline $\begin{array}{l}\text { Convergence on } \\
\text { absorptive capacity }\end{array}$ & $\begin{array}{l}\text { Jansen et al. (2005); Van De Bosch et al. (1999); Tsai and Wu } \\
\text { (2011); Lim (2006); Kogut and Zander (1992); Hopkins et al } \\
\text { (2011); Becker (2014); Becker and Eube (2018) }\end{array}$ \\
\hline
\end{tabular}

Source: Author Constructed 
This study justifies the selection of the variables for the conceptual model for deductive reasoning although the findings of different studies show varying types of relationships.

\section{Conceptual Framework}

The interdependencies between open innovation and innovation performance are very complex. Thus, the choice of variables plays a significant role when empirical research on these relationships is designed (Lopez \& Carvalho, 2018). The planned research is a quantitative study based on deductive reasoning. Having examined what other researchers have already contributed to this domain knowledge, the following conceptual model was developed for the needs of the intended empirical research, Figure 2.

\section{Figure 2: Conceptual Framework}

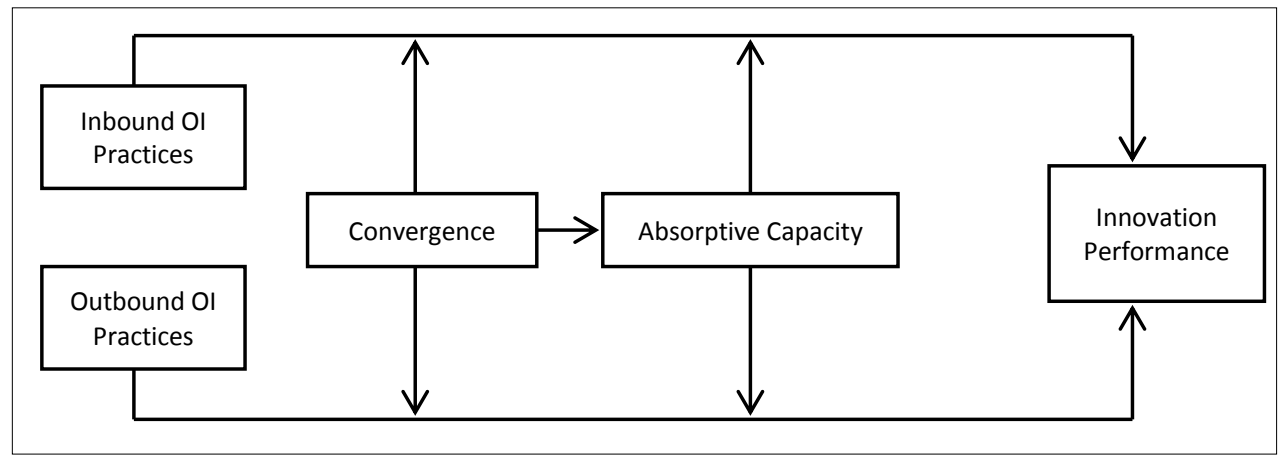

Source: Author Constructed

Accordingly, the following hypotheses are proposed.

H1: Inbound OI has a positive relationship with innovation performance.

H2: Outbound OI has a positive relationship with innovation performance.

H3: Absorptive capacity has a moderating effect on inbound OI and innovation performance.

H4: Absorptive capacity has a moderating effect on outbound OI and innovation performance.

H5: Convergence moderates the relationship between inbound OI and innovation performance. 
H6: Convergence moderates the relationship between outbound OI and innovation performance.

H7: Convergence has a relationship with absorptive capacity.

The above hypotheses will be tested with the data to be collected from software firms.

\section{Justification of the Industry for Empirical Research Study}

As OI practices have become popular among business organisations, software firms are also exposed to the new facets of openness (Munir, 2018) including Sri Lanka. There are many local software companies who have commenced joint R\&D laboratories with national universities. Many firms are harnessing ideas and knowledge from external sources through collaborative projects, competitions etc. Similarly, software firms are attempting to use external parties to early commercialize their ideas, technologies, and solutions through various proprietary and open source business models. Open source software, crowdsourcing, and collaborative tools are becoming popular.

Despite the wide use of open innovation practices of software firms in Sri Lanka, the concerted efforts have not brought the intended innovation performance. Inferior results can be observed in the low number of globally recognized innovative solutions and in low export growth. This situation makes it conducive to use firms in Sri Lanka in our intended research study investigating the connections between open innovation practices and innovation performance. Software firms in Sri Lanka are used as the empirical sample of our study.

Gartner, AT Kearney, Tholons, World Economic Forum, and World Intellectual Property Organisation (WIPO) are some international agencies who have highlighted the immense growth potential the local software firms have in an industry that has recorded a global demand in excess of US\$ 370 billion in 2014 (PricewaterhouseCoopers [PWC], 2016) with high growth potential. Promoting innovations, especially radical or disruptive 
innovations in products, processes and business models is mandatory for the Sri Lankan software industry in order to take full advantage of the grow potential. Sri Lanka has made substantial investments to its education infrastructure and human resources in its Information and Communication Technology (ICT) education (Export Development Board [EDB], 2017) and the country has a competent talent pool with proven competence in par with global standards. However, despite the resources and infrastructure available Sri Lankan software industry is yet to record an annual export revenue of US\$ 1 billion, a target the key stakeholders set a decade back.

\section{Figure 3: Information and Communication Technology Exports from Sri Lanka in US\$ Millions}

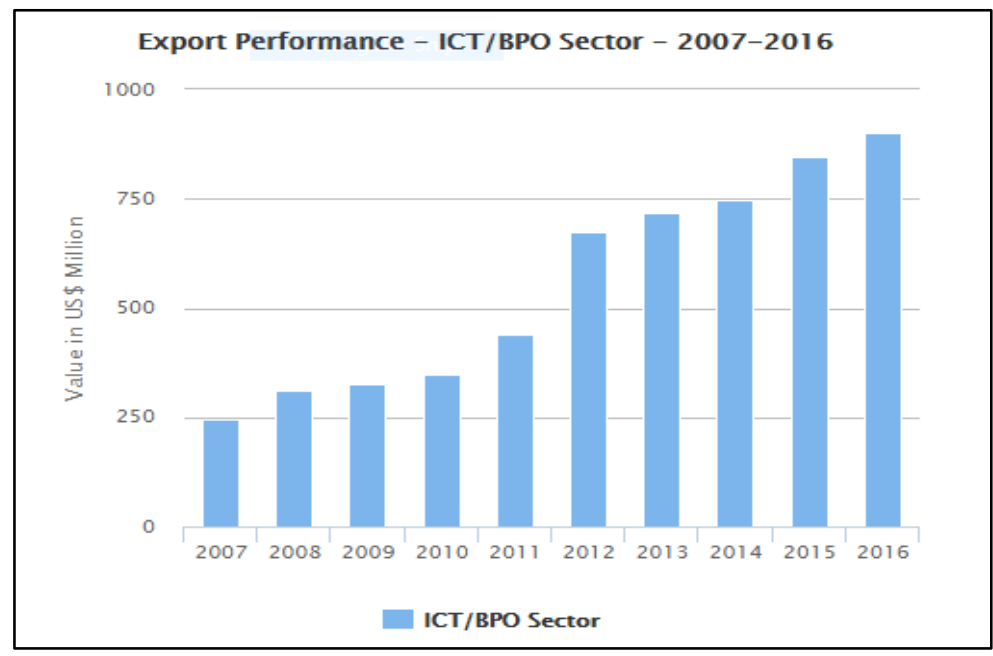

Source: Export Development Board, 2017

Sri Lanka is yet to appear in popular rankings with global software brands. Not one Sri Lankan software firms appears in the Global 100 Software Leaders 2016 ranking published by the PWC. In the same ranking, there are no Sri Lankan firms in the top 30 software companies from the emerging markets. There are only few software companies who have been successful 
in promoting innovative software solutions in global markets under a Sri Lankan brand name.

Figure 4: Comparison of Total Exports and Information and Communication Technology Exports

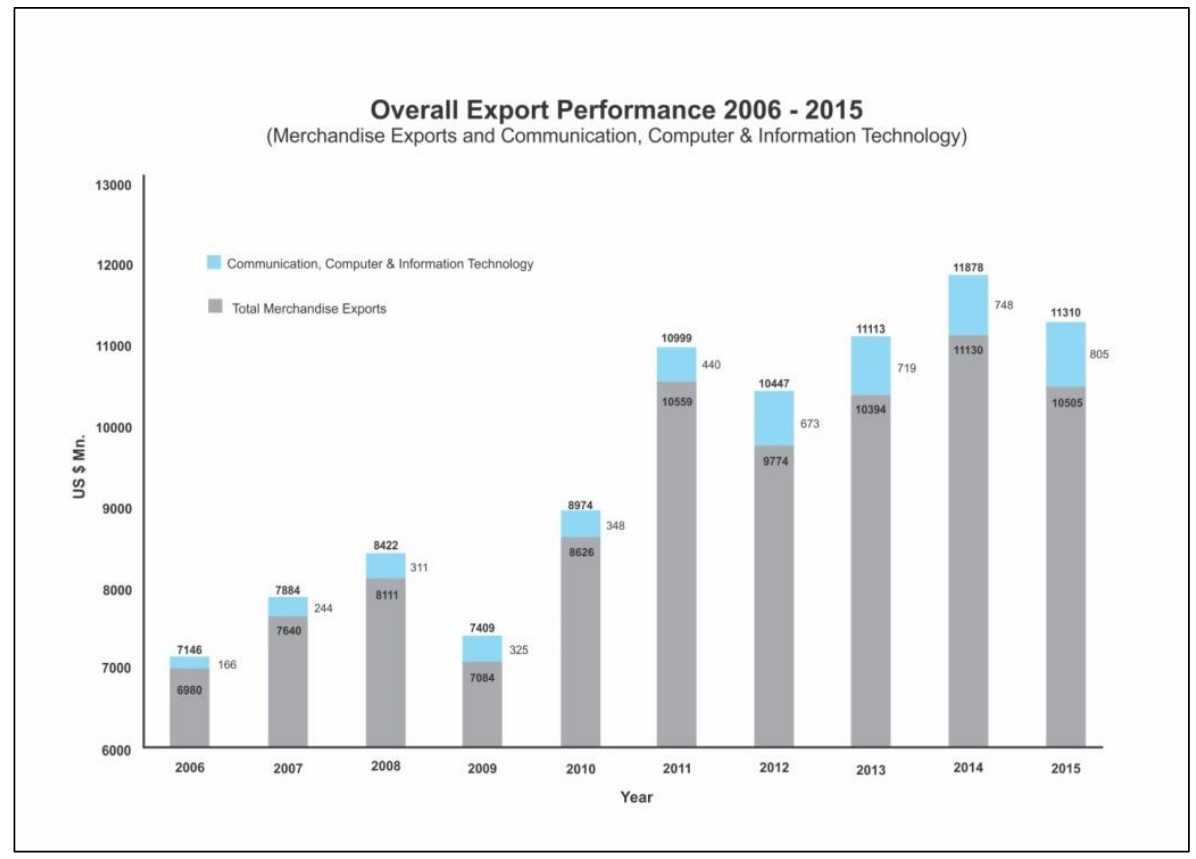

Source: Export Development Board of Sri Lanka

High-tech exports for 2015 accounts less than 1 per cent of total manufactured exports from Sri Lanka as per the statistics of the World Bank (www.data.worldbank.org). Considering how promising field ICT globally is, Sri Lanka is investing heavily to increase the share of ICT in its economy. In 2017, software industry was the fifth most important export sector in Sri Lanka. In order to boost this sector, Sri Lanka is making substantial investments in infrastructure, human resources and ICT education. 
OI involves forging relationships with external parties, which include universities, R\&D institutions, users, buyers, and other firms (Naqshbandi \& Kaur, 2014; Chesbrough, 2003; Emden et al., 2006; Von Hippel, 2005). There are many software companies in Sri Lanka, which have commenced joint $R \& D$ laboratories with national universities. The premier national university in engineering, University of Mortauwa has 12 joint $R \& D$ and innovation laboratories promoted with corporate organisations. In addition, the University of Colombo - School of Computing, Sri Lanka Institute of Information Technology, and the University of Peradeniya also have several joint R\&D laboratories, incubators and innovation centres promoted with leading software firms in the country. A study done by Larsen et al. (2016) on university industry collaborations in Sri Lanka reveals that most of the relationships have been short term and informal which hinders innovation performance.

Collaborative projects and innovation contests are becoming popular practices in harnessing new ideas from outside the companies (Bullinger \& Moeslein, 2011). The ICT community in Sri Lanka is very active and regular knowledge sharing happens through meet-ups, hackathons and competitions (www.icta.lk). There are 25 branded meet-ups, 12 hackathons and 10 annual national competitions. One example is the Young Computer Scientist competition which is organized by the Federation of IT Industry Sri Lanka in collaboration with the Ministry of Education. Another example is the National Best Quality Software Awards, which is organized by the British Computer Society, the Chartered Institute for IT - Sri Lanka Section. Both of these events have been organized annually since 1998 . There is substantial number of other innovation contests in Sri Lanka organized and funded by corporate firms including software companies. Some of these events are telecasted live on a weekly basis in popular television channels.

Web based OI platforms have changed how collaborations happen in innovations (Albors, Ramos, \& Hervas, 2008; De Mattos et al, 2018) as they open up innovation processes of organisations (Parameswaran \& Whinston, 2007; Battistella \& Nonino, 2011). Idea Mart (www.ideamart.lk) is a platform offered by Dialog, Sri Lanka's biggest mobile telecommunications provider. It enables innovators to use innovation tools to build mobile 
applications using Dialog services and reach its customer base of over 10 million customers. Sri Lanka's biggest apparel manufacturer and exporter, MAS Holdings commenced a collaboration space for start-up firms named MAS Innovations to collaborate in promoting innovations. The company also has a subsidiary for software development. Huawei, a global telecommunication giant also commenced a state of the art open innovation laboratory in Sri Lanka. The objective is to harness ideas and knowledge from the user community in Sri Lanka and to promote knowledge transfer for mutual benefits. A fundamental aspect of innovation is making new linkages and associations (Cohen \& Levinthal, 1990; Nelson \& Winter; 1982; Schumpeter, 1934) and the above initiatives intend to lead to creation of new linkages among individuals, firms and associations.

The results of a pilot study conducted using 160 executives and managers representing 114 manufacturing and service firms from diverse industry sectors in Sri Lanka revealed that OI practices are used and popular in all sizes of firms (Yapa \& Senathiraja, 2017). Several detailed interviews the first author conducted with senior staff members in the areas of R\&D and innovations of five leading software firms revealed that innovation performance in terms of number of innovations, profitability, and revenue growth vary among firms and were below expectations. The interviewees emphasized the necessity of coordination of activities and the importance of alignment of goals and management practices with partner firms for deriving the expected benefits from OI practices. The first author also conducted three discussions with members of the academic staff of two universities involved in activities of joint research laboratories. Also these interviewees emphasized the need for effective coordination and compatibility of goals.

The Global Innovation Index 2017 ranks Sri Lanka 90th out of 127 countries. This index is computed by the WIPO in collaboration with the Cornell University and European Institute for Business Administration. The index has been presented for the past 10 years. It is based on seven pillars and three sub-pillars under each of the main pillars. The pillars are;

- institutions (political environment, regulatory environment, and business environment), 
- human capital and research (education, tertiary education, and $R \& D$ ),

- infrastructure (ICT, general infrastructure, and ecological sustainability),

- market sophistication (credit, investment and trade, and competition),

- business sophistication (knowledge workers, innovation linkages, and knowledge absorption),

- knowledge and technology output (knowledge creation, knowledge impact, and knowledge diffusion),

- creative output (intangible assets, creative goods and services, and online creativity).

Despite its overall low ranking, Sri Lanka records relatively higher rankings in the areas of $\mathrm{R} \& \mathrm{D}$ expenditure by business firms (34th place), joint venture and strategic alliances (31st place) and university industry research collaboration (49th place). The former two have been marked as strengths as well. The results from Global Innovation Index also suggest the need of alignment and coordination among innovation partner firms for better innovation performance. In view of the substantial investments by Sri Lanka in software industry where performance is not up to expectations, it is a good source of empirical data to conduct the subject research.

\section{Methodology}

The intended empirical study is conducted as a survey. Respondents for the research will be selected from the member companies of the Software Chapter of the Federation of IT Industry Sri Lanka (FITIS Software Chapter) and Sri Lanka Association of Software and Service Companies. In the research questionnaire, a five point Likert scale will be used.

Evolving innovation literature highlights the importance and popularity of OI practices. Scholars also emphasize the necessity of researching organisational and contextual factors that moderate open innovation performance (Remneland-Wikhamn, 2012; Rass et al., 2013; Cheng \& Huizingh, 2014). Identifying theoretically driven ways to address the challenges of OI is important not only to assist firms to improve performance but also to advance OI literature (Cui, Wu, Tong, 2018). This research will contribute to literature and practicing managers by identifying what influences OI success particularly by examining the degree of 
convergence in inter-organisational networks and factors that can facilitate

OI practices.

\section{References}

Achrol, R. S., Scheer, L. K., \& Stern, L. W. (1990). Designing Successful Transorganisational Marketing Alliances. Retrieved from http://www.msi.org/reports/designing-successful-transorganizationalmarketing-alliances/

Adam, Y., Ong, C. H., \& Pearson, A. W. (1988). Licensing as an alternative to foreign direct investment: An empirical investigation. Journal of Product Innovation Management, 5, 32-49.

Afuah, A., \& Tucci, C. L. (2012). Crowdsourcing as a solution to distant search. Academy of Management Review, 37(3), 355-375.

Al-Belushi, K. I., Stead, S. M., \& Burgess, J. G. (2015). The development of marine biotechnology in Oman: Potential for capacity building through open innovation. Marine Policy, 57, 147-157.

Albors, J., Ramos, J. C., \& Hervas, J. L. (2008). New learning network paradigms: Communities of objectives, crowdsourcing, wikis and open source. International Journal of Information Management, 28(3), 194202.

Almirall, E., \& Casadesus-Masanell, R. (2010). Open versus closed innovation: A model of discovery and divergence. Academy of Management Review, 35(1), 27-47.

Andriopoulos, C., \& Lewis, M. W. (2009). Exploitation-exploration tensions and organisational ambidexterity: Managing paradoxes of innovation. Organisation Science, 20(4), 696-717.

Appleyard, M. M., Chesbrough, H.W., (2017), The dynamics of open strategy: from adoption to reversion. Long Range Plan, 50, 310-321.

Arashpour, M., Abbasi, B., Arashpour, M., Hosseini, M. R., \& Yang, R. (2017). Integrated management of on-site, coordination and off-site uncertainty: theorizing risk analysis within a hybrid project setting. International Journal of Project Management, 35(4), 647-655.

Asakawa, K., Nakamura, H., \& Sawada, N. (2010). Firms' open innovation policies, laboratories' external collaborations, and laboratories' R\&D performance. R\&D Management, 40(2), 109-123.

Barney, J. (1991). Firm resources and sustained competitive advantage. Journal of management, 17(1), 99-120. 
Battistella, C., \& Nonino, F. (2012). Open innovation web-based platforms: The impact of different forms of motivation on collaboration. Journal of Innovation, 14(4), 557-575.

Becker, B. A., \& Eube, C. (2018). Open innovation concept: integrating universities and business in digital age. Journal of Open Innovation: Technology, Market, and Complexity, 4(1), 12-23.

Behnam, S., Cagliano, R., \& Grijalvo, M. (2018). How should firms reconcile their open innovation capabilities for incorporating external actors in innovations aimed at sustainable development? Journal of Cleaner Production, 170, 950-965.

Bengtsson, L., Lakemond, N., Lazzarotti, V., Manzini, R., Pellegrini, L., \& Tell, F. (2015). Open to a select few? Matching partners and knowledge content for open innovation performance. Creativity and innovation Management, 24(1), 72-86.

Berchicci, L. (2013). Towards an open R\&D system: Internal R\&D investment, external knowledge acquisition and innovative performance. Research Policy, 42(1), 117-127.

Bianchi, M. Croce, A. Dell'ella, C., Di Benedetto, C. A., \& Frattini, F. (2015). Organizing for inbound open innovation: How external consultants and a dedicated R\&D unit influence product innovation performance. Journal of Product Innovation Management, 33(4), 492510 .

Billington, C., \& Davidson, R. (2013). Leveraging open innovation using intermediary networks. Production and Operations Management, 22(6), 1464-1477.

Bogers, M., Zobel, A.K., Afuah, A., Almirall, E., Brunswicker, S., Dahlander, L., Frederiksen, L., Gawer, A., Gruber, M., Haefliger, S., \& Hagedoorn, J. (2017). The open innovation research landscape: Established perspectives and emerging themes across different levels of analysis. Industry and Innovation, 24(1), 8-40.

Bourgeois, L. J. (1980). Performance and consensus. Strategic management Journal, 1(3), 227-248.

Bucklin, L. P., \& Sengupta, S. (1993). Organizing successful co-marketing alliances. The Journal of Marketing,57(2), 32-46.

Bullinger, A. C., \& Moeslein, K.M. (2011). Innovation Contests: Systematization of the field and future research. International Journal of Virtual Communities and Social Networking, 3, 1-12. 
Callon, M. (1999). Actor-network theory-the market test. The Sociological Review, 47(1), 181-195.

Callon, M., Laredo, P., Rabeharisoa, V., Gonard, T., \& Leray, T. (1992). The management and evaluation of technological programs and the dynamics of techno-economic networks: The case of the AFME. Research Policy, 21(3), 215-236.

Caputo,M., Lambert, E., Cammarano, A., Michelino, F. (2016). Exploring the impact of open innovation on firm performance. Management Decisions, 54, 1788-1812.

Chaston, I. (2013). Independent financial advisors: open innovation and business performance. The Service Industries Journal, 33(6), 636-651.

Chen, J., Zhao, X., \& Wang, Y. (2014). A new measurement of intellectual capital and its impact on innovation performance in an open innovation paradigm. International Journal of Technology Management, 67(1), 125.

Cheng, C. C., \& Huizingh, E. K. (2014). When is open innovation beneficial? The role of strategic orientation. Journal of Product Innovation Management, 31(6), 1235-1253.

Cheng, C. C., \& Shiu, E. C. (2015). The inconvenient truth of the relationship between open innovation activities and innovation performance. Management Decision, 53(3), 625-647.

Cheng, C. C., Yang, C., \& Sheu, C. (2016). Effects of open innovation and knowledge-based dynamic capabilities on radical innovation: An empirical study. Journal of Engineering and Technology Management, 41, 79-91.

Chesbrough, H. (2003). The logic of open innovation: managing intellectual property. California Management Review, 45(3), 33-58

Chesbrough, H. (2017). The future of open innovation, ResearchTechnology Management, 60(6), 29-35.

Clausen, T. H. (2013). External knowledge sourcing from innovation cooperation and the role of absorptive capacity: empirical evidence from Norway and Sweden. Technology Analysis \& Strategic Management, 25(1), 57-70.

Cohen, W. M., \& Levinthal, D. A. (1990). Absorptive capacity: A new perspective on learning and innovation. Administrative science quarterly, 35(1), 128-152. 
Colombo, M. G., Piva, E., \& Rossi-Lamastra, C. (2014). Open innovation and within-industry diversification in small and medium enterprises: The case of open source software firms. Research Policy, 43(5), 891902.

Corsaro, D., \& Snehota, I. (2011). Alignment and misalignment in business relationships. Industrial Marketing Management, 40(6), 1042-1054.

Cui, T., Wu, Y., \& Tong, Y. (2018). Exploring ideation and implementation openness in open innovation projects: IT-enabled absorptive capacity perspective. Information \& Management 55, 576-587.

Pedrosa, D. M. A., Välling, M., \& Boyd, B. (2013). Knowledge related activities in open innovation: managers' characteristics and practices. International Journal of Technology Management 12, 61(3/4), 254-273.

Dahlander, L., \& Piezunka, H. (2014). Open to suggestions: How organisations elicit suggestions through proactive and reactive attention. Research Policy, 43(5), 812-827.

De Mattos, C. A., Kissimoto, K. O., \& Laurindo, F. J. B. (2018). The role of information technology for building virtual environments to integrate crowdsourcing mechanisms into the open innovation process. Technological Forecasting and Social Change, 129, 143-153.

De Noni, I., Orsi, L., \& Belussi, F. (2018). The role of collaborative networks in supporting the innovation performances of lagging-behind European regions. Research Policy, 47(1), 1-13.

De Zubielqui, G. C., Jones, J., \& Lester, L. (2016). Knowledge inflows from market and science based actors, absorptive capacity, innovation and performance: A study of SMEs. International Journal of Innovation Management, 20(06), 1650055.

Duysters, G., \& Man, A. P. (2003). Transitory alliances: an instrument for surviving turbulent industries? R\&D Management, 33(1), 49-58.

Emden, Z., Calantone, R. J., \& Droge, C. (2006). Collaborating for new product development: selecting the partner with maximum potential to create value. Journal of product innovation management, 23(4), 330341.

Enkel, E., Gassmann, O., \& Chesbrough, H. (2009). Open R\&D and open innovation: exploring the phenomenon. R\&D Management, 39(4), 311316. 
Enkel, E, \& Heil, S. (2014). Preparing for distant collaboration: Antecedents to potential absorptive capacity in cross-industry innovation. Technovation, 34(4), 242-260.

Escribano, A., Fosfuri, A., \& Tribó, J. A. (2009). Managing external knowledge flows: The moderating role of absorptive capacity. Research Policy, 38(1), 96-105.

Export Development Board, Sri Lanka (2017). ICT services. Retrieved from http://www.srilankabusiness.com/export-services/ict/ict-exportperformance.html

Fabrizio, K. R. (2009). Absorptive capacity and the search for innovation. Research policy, 38(2), 255-267.

Felin, T., \& Zenger, T. R. (2014). Closed or open innovation? Problem solving and the governance choice. Research Policy, 43(5), 914-925.

Fernandes, S., Cesario, M., Barata, J. M. (2017). Ways to open innovation: Main agents and the sources in the Portuguese case. Technology in Society, 51, 153-162.

Ferrary, M. (2011). Specialized organisations and ambidextrous clusters in the open innovation paradigm. European Management Journal, 29(3), 181-192.

Ferto, I., Molnar, A., \& Tóth, J. (2016). Borderless ideas-open innovation in the Hungarian food chain. British Food Journal, 118(6), 1494-1515.

Fiegenbaum, I., Ihrig, M., \& Torkkeli, M. (2014). Investigating open innovation strategies: a simulation study. International Journal of Technology Management, 66(2-3), 183-211.

Flor, M. L., Cooper, S. Y., \& Oltra, M. J. (2017). External knowledge search, absorptive capacity and radical innovation in high-technology firms. European Management Journal.36(2), 183-194.

Foroughi, A., Buang, N. A., Senik, Z. C., Hajmirsadeghi, R. S., \& Bagheri, M. M. (2015). The role of open service innovation in enhancing business performance: the moderating effects of competitive intensity. Current Science, 109(4), 691-698.

Foss, N. J., Laursen, K., \& Pedersen, T. (2011). Linking customer interaction and innovation: The mediating role of new organisational practices. Organisation Science, 22(4), 980-999.

Garriga, H., Von Krogh, G., \& Spaeth, S. (2013). How constraints and knowledge impact open innovation. Strategic Management Journal, 34(9), 1134-1144. 
Ghisetti, C., Marzucchi, A., \& Montresor, S. (2015). The open ecoinnovation mode. An empirical investigation of eleven European countries. Research Policy, 44(5), 1080-1093.

Godkin, L. (2010). The zone of inertia: absorptive capacity and organisational change. The Learning Organisation, 17(3), 196-207.

Greco, M., Locatelli, G., \& Lisi, S. (2017). Open innovation in the power \& energy sector: Bringing together government policies, companies' interests, and academic essence. Energy Policy, 104, 316-324.

Haythornthwaite, C. (1996). Social network analysis: An approach and technique for the study of information exchange. Library \& information science research, 18(4), 323-342.

He, Z.L. and Wong, P. K., (2004). Exploration vs exploitation: An empirical test of the ambidexterity hypothesis. Organisation Science 15(4), 481494.

Hernandez-Vivanco, A., Bernardo, M., \& Cruz-Cázares, C. (2016). Relating open innovation, innovation and management systems integration. Industrial Management \& Data Systems, 116(8), 1540-1556.

Hippel, E. V., \& Krogh, G. V. (2003). Open source software and the private-collective innovation model: Issues for organisation science. Organisation science, 14(2), 209-223.

Hopkins, M. M., Tidd, J., Nightingale, P., \& Miller, R. (2011). Generative and degenerative interactions: Positive and negative dynamics of open, user-centric innovation in technology and engineering consultancies. $R \& D$ Management, 4l(1), 44-60.

Hossain, M., \& Anees-ur-Rehman, M. (2016). Open innovation: an analysis of twelve years of research. Strategic Outsourcing: An International Journal, 9(1), 22-37.

Hossain, M., \& Kauranen, I. (2016). Open innovation in SMEs: a systematic literature review. Journal of Strategy and Management, 9(1), 58-73.

Huang, F., \& Rice, J. (2012). Openness in product and process innovation. International Journal of Innovation Management, 16(04), 1250020.

Huang, H. C., Lai, M. C., \& Huang, W. W. (2015). Resource complementarity, transformative capacity, and inbound open innovation. Journal of Business \& Industrial Marketing, 30(7), 842-854. 
Huang, H. C., Lai, M. C., Lin, L. H., \& Chen, C. T. (2013). Overcoming organisational inertia to strengthen business model innovation: An open innovation perspective. Journal of Organisational Change Management, 26(6), 977-1002.

Huizing, E. K. R. E. (2011). Open innovation: State of the art and future perspective. Technovation, 31, 2-9.

Jansen, J. J., Van Den Bosch, F. A., \& Volberda, H. W. (2005). Exploratory innovation, exploitative innovation and ambidexterity: The impact of environmental and organisational antecedents. Schmalenbach Business Review, 57(4), 351-363.

Kallio, A., Harmaakorpi, V., \& Pihkala, T. (2010). Absorptive capacity and social capital in regional innovation systems: The case of the Lahti region in Finland. Urban Studies, 47(2), 303-319.

Kim, B., Kim, E., \& Foss, N. J. (2016). Balancing absorptive capacity and inbound open innovation for sustained innovative performance: An attention-based view. European Management Journal, 34(1), 80-90.

Kim, N., Kim, D. J., \& Lee, S. (2015). Antecedents of open innovation at the project level: empirical analysis of Korean firms. $R \& D$ Management, 45(5), 411-439.

Kogut, B., \& Zander, U. (1992). Knowledge of the firm, combinative capabilities, and the replication of technology. Organisation Science, 3(3), 383-397.

Koruna, S. (2004). External technology commercialization - policy guidelines. International Journal of Technology Management, 27, 241254.

Kutvonen, A. (2009), Strategic application of outbound open innovation. European Journal of Innovation Management, 14(4), 460-474

Lakemond, N., Bengtsson, L., Laursen, K., \& Tell, F. (2016). Match and manage: The use of knowledge matching and project management to integrate knowledge in collaborative inbound open innovation. Industrial and Corporate Change, 25(2), 333-352.

Larsen, K., Bandara, D.C., Mohamed, E., \& Unantenne, R. (2016). Promoting university-industry collaborations in Sri Lanka: Status, case studies \& policy options. Washington DC: International Bank for Reconstruction \& Development, The World Bank.

Latour, B. (1996). On actor-network theory: A few clarifications. Soziale Welt, 47(4), 369-381. 
Latour, B. (2005). Reassembling the social: An introduction to actornetwork-theory. UK: Oxford University Press.

Laursen, K., \& Salter, A. (2006). Open for innovation: the role of openness in explaining innovation performance among UK manufacturing firms. Strategic Management Journal, 27(2), 131-150.

Lee, B., Cho, H. H., \& Shin, J. (2015). The relationship between inbound open innovation patents and financial performance: evidence from global information technology companies. Asian Journal of Technology Innovation, 23(3), 289-303.

Lee, J., Kao, H. A., \& Yang, S. (2014). Service innovation and smart analytics for industry 4.0 and big data environment. Procedia Cirp, 16, 3-8.

Lee, S. M., \& Shin, J. (2017). A path to collaborative innovation through internal boundary breaking. Research-Technology Management, 60(4), 26-32.

Leminen, S., Turunen, T., \& Westerlund, M. (2015). The grey areas between open and closed in innovation networks. Technology Innovation Management Review, 5(12), 6-18.

Lewandowska, L. (2014). Franchising as a way of creating entrepreneurship and innovation. Comparative Economic Research, 17(3), 163-181.

Lim, K. (2009). The many faces of absorptive capacity: Spillovers of copper interconnect technology for semiconductor chips. Industrial and Corporate Change, 18(6), 1249-1284.

Lopes, A. P. V. B. V. \& Carvalho, M. M. D. (2018). Evolution of the open innovation paradigm: Towards a contingency conceptual model. Technological Forecasting \& Social Change, 132, 284-298.

Lopez-Vega, H., Tell, F., \& Vanhaverbeke, W. (2016). Where and how to search? Search paths in open innovation. Research Policy, 45(1), 125136.

Lu, P., Yuan, S., \& Wu, J. (2017). The interaction effect between intraorganisational and inter-organisational control on the project performance of new product development in open innovation. International Journal of Project Management, 35(8), 1627-1638.

March, J. G. (1991). Exploration and exploitation in organisational learning. Organisation Science, 2(1), 71-87. 
Matusik, S. F., \& Heeley, M. B. (2005). Absorptive capacity in the software industry: Identifying dimensions that affect knowledge and knowledge creation activities. Journal of Management, 31(4), 549-

Mazzola, E., Bruccoleri, M., \& Perrone, G. (2016). Open innovation and firms performance: state of the art and empirical evidences from the bio-pharmaceutical industry. International Journal of Technology Management, 70(2-3), 109-134.

Meyer, J. W., \& Rowan, B. (1977). Institutionalized organisations: Formal structure as myth and ceremony. American Journal of Sociology, 83(2), 340-363.

Miere O \& Missonier S (2012). Trajectory of an IT project network: Convergence, divergence and adjustment process, Paper presented at the European Conference on Information Systems 2012, Barcelona, Spain. Paper retrieved from https://aisel.aisnet.org/ecis2012/

Mina, A., Bascavusoglu-Moreau, E., \& Hughes, A. (2014). Open service innovation and the firm's search for external knowledge. Research Policy, 43(5), 853-866.

Moller, K. Svahn, S. (2009). How to influence the birth of new business fields - Network perspective. Industrial Marketing Management, 38(4), 450-458.

Moretti, F., \& Biancardi, D. (2018). Inbound open innovation and firm performance. Journal of Innovation \& Knowledge. Advance online publication. doi: 10.1016/j.jik.2018.03.001

Munir, H., Linaker, J., Wnuk, K., Runeson, P., Regnell, B. (2018) Open innovation using open source tools: A case study at Sony Mobile. Empr Software Engineering, 23, 186-233.

Murovec, N., \& Prodan, I. (2009). Absorptive capacity, its determinants, and influence on innovation output: Cross-cultural validation of the structural model. Technovation, 29(12), 859-872.

Najafian, M., \& Colabi, A. M. (2014). Inter-organisational relationship and innovation: A review of literature. Global Business and Management Research, 6(1), 52.

Naqshbandi, M. M. (2016). Managerial ties and open innovation: examining the role of absorptive capacity. Management Decision, 54(9), 22562276. 
Naqshbandi, M. M. (2018). Organisational characteristics and engagement in open innovation: Is there a link? Global Business Review, 19(3S), 120.

Naqshbandi, M., \& Kaur, S. (2014). Do managerial ties support or stifle open innovation? Industrial Management \& Data Systems, 114(4), 652675.

Nelson, R. R., \& Winter, S. G. (2009). An evolutionary theory of economic change. Cambridge, MA: Harvard University Press.

Nitzsche, P., Wirtz, B. W., \& Gottel, V. (2016). Innovation success in the context of inbound open innovation. International Journal of Innovation Management, 20(2).

Noh, Y. (2015). Financial effects of open innovation in the manufacturing industry. Management Decision, 53(7), 1527-1544.

Parameswaran, M., \& Whinston, A. B. (2007). Social computing: An overview. Communications of the Association for Information Systems, 19(1), 37.

Parida, V., Westerberg, M., \& Frishammar, J. (2012). Inbound open innovation activities in high-tech SMEs: The impact on innovation performance. Journal of Small Business Management, 50(2), 283-309.

Pilav-Velic, A., \& Marjanovic, O. (2016). Integrating open innovation and business process innovation: Insights from a large-scale study on a transition economy. Information \& Management, 53(3), 398-408.

Pilav-Velic, A., \& Marjanovic, O. (2016). Integrating open innovation and business process innovation: Insights from a large-scale study on a transition economy. Information \& Management, 53(3), 398-408.

Popa, S., Soto-Acosta, P., \& Martinez-Conesa, I. (2017). Antecedents, moderators, and outcomes of innovation climate and open innovation: An empirical study in SMEs. Technological Forecasting and Social Change, 118, 134-142.

Porto Gomez, I., Otegi Olaso, J. R., \& Zabala-Iturriagagoitia, J. M. (2016). Trust builders as open Innovation intermediaries. Innovation, 18(2), 145-163.

Powell, W. W., Koput, K. W., \& Smith-Doerr, L. (1996). Interorganisational collaboration and the locus of innovation: Networks of learning in biotechnology. Administrative Science Quarterly, 4l(1), 116-145. 
Prabhu, J. C., Chandy, R. K., \& Ellis, M. E. (2005). The impact of acquisitions on innovation: poison pill, placebo, or tonic? Journal of Marketing, 69(1), 114-130.

Provan, K. G., \& Milward, H. B. (1995). A preliminary theory of interorganisational network effectiveness: A comparative study of four community mental health systems. Administrative Science Quarterly, 40(1), 1-33.

Pullen, A. J., Weerd-Nederhof, P. C., Groen, A. J., \& Fisscher, O. A. (2012). Open innovation in practice: Goal complementarity and closed NPD networks to explain differences in innovation performance for SMEs in the medical devices sector. Journal of product innovation management, 29(6), 917-934.

Pricewaterhousecoopers (2016). Vision 2022 ICT BPO sector. Sri Lanka association of software \& service companies. Colombo, Sri Lanka: Author.

Rampersad, G., Quester, P., \& Troshani, I. (2010). Managing innovation networks: Exploratory evidence from ICT, biotechnology and nanotechnology networks. Industrial Marketing Management, 39(5), 793-805.

Randhawa, K., Wilden, R., \& Hohberger, J. (2016), A bibliometric review of open innovation: Ssetting a research agenda. Journal of Production \& Innovation Management, 33, 750-772.

Rass, M., Dumbach, M., Danzinger, F., Bullinger, A. C., \& Moeslein, K. M. (2013). Open innovation and firm performance: The mediating role of social capital. Creativity and innovation management, 22(2), 177-194.

Remneland-Wikhamn, B., \& Knights, D. (2012). Transaction cost economics and open innovation: Implications for theory and practice. Creativity and Innovation Management, 21(3), 277-289.

Rothaermel, F. T., \& Alexandre, M. T. (2009). Ambidexterity in technology sourcing: The moderating role of absorptive capacity. Organisation Science, 20(4), 759-780.

Rothwell, R. (1977). The characteristics of successful innovators and technically progressive firms (with some comments on innovation research). $R \& D$ Management, $7(3), 191-206$. 
Ruekert, R. W., \& Walker Jr, O. C. (1987). Marketing's interaction with other functional units: A conceptual framework and empirical evidence. The Journal of Marketing, 50(1), 1-19.

Rusanen, H. (2013, January). Finding the right partners for innovation networks. Paper presented at the XXIV International Society for Professional Innovation Management Conference, Helsinki, Finland. Retrieved from https://www.researchgate.net/publication/236949958_Finding_the_right _partner_for_innovation_networks

Saebi, T., \& Foss, N. J. (2015). Business models for open innovation: Matching heterogeneous open innovation strategies with business model dimensions. European Management Journal, 33(3), 201-213.

Schumpeter, J. A. (1983). The theory of economic development: An inquiry into profits, capital, credit, interest, and the business cycle. Piscataway, NJ: Transaction Publishers.

Sikimic, U., Chiesa, V., Frattini, F., \& Scalera, V. G. (2016). Investigating the influence of technology inflows on technology outflows in open innovation processes: A longitudinal analysis. Journal of Product Innovation Management, 33(6), 652-669.

Sisodiya, S. R., Johnson, J. L., \& Gregoire, Y. (2013). Inbound open innovation for enhanced performance: Enablers and opportunities. Industrial Marketing Management, 42(5), 836-849.

Salter, A., Ter wal, A. L. J., \& Criscuolo, P., \&Alexy, O. (2014). Open for ideation: Individual level openness and idea generation in R\&D. Journal of Product Innovation Management, 32(4), 488-504.

Soh, P. H., \& Roberts, E. B. (2003). Networks of innovators: a longitudinal perspective. Research Policy, 32(9), 1569-1588.

Spekman, R. E., Isabella, L. A., \& MacAvoy, T. C. (2000). Alliance competence: Maximizing the value of your partnerships. New York: John Wiley \& Sons Inc.

Spithoven, A., Clarysse, B., \& Knockaert, M. (2011). Building absorptive capacity to organise inbound open innovation in traditional industries. Technovation, 31(1), 10-21.

Teece, D. J., Pisano, G., \& Shuen, A. (1997). Dynamic capabilities and strategic management. Strategic Management Journal, 18(7), 509-533. 
Tichy, N. M., Tushman, M. L., \& Fombrun, C. (1979). Social network analysis for organisations. Academy of Management Review, 4(4), 507519.

Tomlinson, P.R. (2010). Co-operative ties and innovation: Some new evidence for UK manufacturing. Research Policy 39, 762-775.

Tsai, Y. C., \& Wu, C. S. (2011). The effects of inter-partner resource alignment and absorptive capacity on knowledge transfer performance. African Journal of Business Management, 5(26), 10434.

Tushman, M. L., \& O'Reilly, C. A. (1996). The ambidextrous organisations: Managing evolutionary and revolutionary change. California Management Review, 38(4), 8-30.

Un, C. A., Cuervo-Cazurra, A., \& Asakawa, K. (2010). R\&D collaborations and product innovation. Journal of Product Innovation Management, 27(5), 673-689.

Uzzi, B. (1996). The sources and consequences of embeddedness for the economic performance of organisations: The network effect. American Sociological Review, 61(4), 674-698.

Van Den Bosch, F.A. G., Volberda, H.W. \& De Boer, M. (1999). Coevolution of firm absorptive capacity and knowledge environment: Organisational forms and combinative capabilities. Organisation Science, 10(5), 551-568.

Vanhaverbeke, W. (2006). The interorganisational context of open innovation. In Hery, C., Vanhaverbeke, W., \& Joel, W. (Eds), Open innovation: Researching a new paradigm, (pp. 205-219). Oxford: Oxford University Press.

Verbano C., Venturini, K., \& Wasser A. (2013). The evolution of resources in research based spin-offs: Learning from a case study. Proceedings of the 8th European Conference on Innovation and Entrepreneurship (pp. 623-632). Brussels: University of Aveiro.

Von Hippel, E. (2005). Open source software projects as user innovation networks. In Feller, J., Fitzgerald, B., Hissam, S., \& Lakhani, K. (Eds), In perspectives on free and open source software, (pp. 267-278). Cambridge: MIT Press.

Von Krogh, G., Netland, T., \& Wörter, M. (2018). Winning With Open Process Innovation. MIT Sloan Management Review, 59(2), 53-56. 
West, J., \& Bogers, M. (2014). Leveraging external sources of innovation: A review of research on open innovation. Journal of Product Innovation Management, 31(4), 814-831.

West, J., \& Gallagher, S. (2006). Challenges of open innovation: Tthe paradox of firm investment in open-source software. $R \& D$ Management, 36(3), 319-331.

Williamson, O. E. (1975). Markets and hierarchies: Analysis and antitrust implications: A study in the economics of internal organisation. Retrieved from https://pdfs.semanticscholar.org/51e0/624399096cb1bbf76f358f1fc790b 274d4cd.pdf

Wynarczyk, P., Piperopoulos, P., \& McAdam, M. (2013). Open innovation in small and medium-sized enterprises: An overview. International Small Business Journal, 31(3), 240-255.

Xie, X., Fang, L., \& Zeng, S. (2016). Collaborative innovation network and knowledge transfer performance: A fsQCA approach. Journal of Business Research, 69(11), 5210-5215.

Yapa, S. R. \& Senathiraja, R. (2017). Inbound open innovation: Whom to converge with and why? Paper presented at the International Conference on the Humanities and the Social Sciences, University of Peradeniya, Sri Lanka.

Zahra, S. A., \& George, G. (2002). Absorptive capacity: A review, reconceptualization, and extension. Academy of Management Review, 27(2), 185-203. 